\title{
Development and initial validation of a Perceived Future Employability Scale for young adults
}

\author{
William Gunawan, Peter Creed, and Ian Glendon \\ School of Applied Psychology \\ Griffith University, Australia
}

\section{Cite as:}

Gunawan, W., Creed, P. A., \& Glendon, I. (2018). Development and initial validation of a perceived future employability scale for young adults. Journal of Career Assessment. doi:10.1177/1069072718788645

\begin{abstract}
This study reports on development and initial validation of a scale to measure young adults' perceptions of their future employability. Perceived future employability concerns young people's perceptions of their future skills, experience, networks, personal traits, labour market knowledge, and institutional reputation at the time of completing their formal education, when they are on the verge of entering the labour market. In Phase 1, an initial item pool was developed from focus group discussions and expert feedback. In Phase 2, exploratory factor analyses reduced the number of items using data from a university student sample $(N=324)$. In Phase 3, confirmatory factor analyses tested the initial structure using data from a second sample of university students $(N=250)$. In Phase 4 , construct validity was examined by correlating scale scores with measures of career ambition, university commitment, and career distress. The scale potentially: (a) augments research on perceived future employability, (b) illuminates factors promoting employability and wellbeing in young adults, and (c) provides information to young adults who are concerned about their future career.
\end{abstract}

Keywords: perceived future employability, career ambition, university commitment, future self, career distress, scale development 


\section{Introduction}

Perceived employability, or an individual's perception of the chances of obtaining and/or maintaining employment (Akkermans \& Kubasch, 2017; Vanhercke, De Cuyper, Peeters, \& De Witte, 2014), is important for career goal-setting and goal-management, and for how individuals behave, think, and feel about their occupation or career (Fugate, Kinicki, \& Ashforth, 2004; Van der Heijde \& Van der Heijden, 2005). Perceived future employability refers to the representation

of one's career self in the future (Ellen, Wiener, \& Fitzgerald, 2012). For young adults, perceived future employability refers to how employable they perceive themselves to be in the future after training, education, and personal development (i.e., after completing their education and/or training and are ready to enter the labour market). As no measures are currently available to assess perceived future employability, this paper reports on a study that developed and provided initial validation of a scale to measure this important construct.

\section{The employability construct}

First used at the beginning of the 20th century, the concept of employability differentiated between "employable" individuals (capable and willing and/or needing to work), and those who were "unemployable" (unable to work and needing help; Gazier, 1998). By the 1950s and 1960s, the concept had shifted to refer more to an attitude about work and the self, and in the 1970s was used to refer to the knowledge and abilities required for work. In the 1980s, it related to the transferable skills required for labour market flexibility, and since the 1990s, employability has referred to how individuals might maintain their job readiness, especially if they were at risk of having to change jobs (Guilbert, Bernaud, Gouvernet, \& Rossier, 2016). The notion of “interactive employability", which focused on individual adaptation, was introduced towards the end of the 20th century (Gazier, 1998). The construct has attracted much attention from 
governments, researchers, and professionals, and has been studied in various disciplines, including economics, education, and psychology (Rothwell, Jewell, \& Hardie, 2009; Vanhercke, et al., 2014).

Rothwell et al. (2009) identified three perspectives on employability: at the national workforce level (e.g., related to government policy), the human resource management (HRM) level (e.g., considered as a component of human resource strategy), and the individual level (e.g., emphasizing individual beliefs about their employment options). The current study focused on the individual or psychological level, which is important to understanding individual perceptions of employability, and allows insight into processes that young people might use to take control of, and manage, their own career progress. Managing their own career progress has the potential to maximise benefits and satisfaction, as emergent workforce members strive for, and meet, their own needs and goals (DiRenzo, Greenhaus, \& Weer, 2011; Weng \& McElroy, 2012; Weng, McElroy, Morrow, \& Liu, 2010).

\section{Perceived employability}

The individual perspective focuses on the person's own "perceived employability" (Berntson \& Marklund, 2007), which “...potentially provides the individual with a feeling of security and a feeling of independence towards environmental circumstances" (Berntson, 2008, p. 19). Perceived employability has been examined in various groups and situations, including undergraduate students entering the labour market (Knight \& Yorke, 2004; Pool \& Qualter, 2013; Pool, Qualter, \& Sewell, 2014), older workers (Van der Heijde \& Van der Heijden, 2005), temporarily employed workers (De Cuyper \& DeWitte, 2010), unemployed (McArdle, Waters, Briscoe, \& Hall, 2007) and long-term unemployed people (Koen, Klehe, \& Van Vianen, 2013), 
people who have been released from prison (Graffam, Shinkfield, \& Hardcastle, 2008), and those with disabilities (Bricout \& Bentley, 2000).

Perceived employability has been defined as the individual's perception of their own possibilities for maintaining existing, or finding new, employment (Berntson \& Marklund, 2007; Vanhercke et al., 2014). It also has been referred to as self-perceived employability (Rothwell, Herbert, \& Rothwell, 2008), graduate employability (Pool et al., 2014), or simply employability (Harvey, 2001; Hillage \& Pollard, 1998; Knight \& Yorke, 2004; van der Heijde, 2014; van der Heijde \& van der Heijden, 2005). While these references indicate that the concept is widespread (Berntson, Naswall, \& Sverke, 2010; Rothwell \& Arnold, 2007), it remains “....in the relatively early stages of conceptual development" (Akkermans \& Kubasch, 2017, p. 592). However, these perspectives have not been built on robust scientific theories, and definitions have tended to reflect researchers' own perspectives. Thus, there is a need for more theoretical development and conceptual clarity for the construct (Akkermans \& Kubbasch, 2017).

\section{Dimensions of perceived employability}

Several facets of perceived employability have been identified, including perceived skills, experience, network, personal characteristics, and labour market knowledge (Berntson \& Marklund, 2007). Perceived skills encompass generic and job skills and related knowledge (Rothwell \& Arnold, 2007; van der Heijde \& van der Heijden, 2005), academic achievement (Pool et al., 2014; Rothwell et al., 2008), skilful practice (Knight \& Yorke, 2004), job seeking skills, and employability assets (Harvey, 2001; Hillage \& Pollard, 1998); all competencies related to obtaining and maintaining employment. Perceived experience includes job, work, and life experiences (Pool et al., 2014; Rothwell \& Arnold, 2007), while networking refers to the extent and usefulness of the individual's work and social connections (Rothwell \& Arnold, 2007; 
van der Heijde \& van der Heijden, 2005), especially those providing information on available jobs.

Personal characteristics refer to capacities related to learning and enhancing oneself and one's skills (Rothwell \& Arnold, 2007), and include agentic qualities that drive flexibility and adaptability, such as anticipation, self-efficacy, metacognitive competencies (Knight \& Yorke, 2004; van der Heijde \& van der Heijden, 2005), emotional intelligence, problem solving, and self-management (Pool et al., 2014). Labour market knowledge covers awareness of opportunities in the labour market (Rothwell \& Arnold, 2007; Rothwell et al., 2008), organizational and job sense (Harvey, 2001; Knight \& Yorke, 2004; van der Heijde \& van der Heijden, 2005), understanding career development and self-management (Pool et al., 2014), and adopting a strategic approach to occupational success (Hillage \& Pollard, 1998). Based on these dimensions, perceived employability in the current study is considered to be an individual's appraisal of their own skills, experience, networks, personal traits, and labour market knowledge.

\section{Existing measures of perceived employability}

Currently available self-perceived employability measures are either unsuitable for use with young adults, as they were constructed to measure perceived employability in individuals who were already in work (e.g., Berntson \& Marklund, 2007; Rothwell \& Arnold, 2007), or were designed to measure current employability in young adults rather than perceptions of future employability after completing education/training (e.g., Pool et al., 2014; Rothwell et al., 2008).

For example, Rothwell et al. (2008) designed a self-perceived employability scale for undergraduate students, which was modified from the Self-Perceived Employability Scale for adults (Rothwell \& Arnold, 2007), and Pool et al. (2014) developed the Employability 
Development Profile, which was designed for use with students from higher education institutions.

\section{Perceived future employability}

For young adults, perceived future employability is the representation of their occupational self after they have completed their study and/or training. Future selves (including future occupational selves) refers to an individual's specific, individualized representations of what they might become (cf. future selves theory: Cross \& Markus, 1991; Ellen et al., 2012; Markus \& Nurius, 1986). Possible selves stimulate goal setting, planning, and goal striving behaviours; that is, they “...provide the means-ends patterns for new behaviors” (Markus \& Nurius 1986, p. 955). Thus, future selves can be considered to result from: “...the construction of prospective self-representations in terms of hopes and fears [that are] seen to provide a basis for anticipating future events, setting goals, planning, exploring options, making commitments, and subsequently guiding a developmental course" (Creed \& Klisch, 2005, p. 252).

From this perspective, the perceived future employability of young adults drives their current occupational thoughts, affect, and behaviours. The relationship between future images and current behaviours has been demonstrated in a number of domains (Comello, 2015). For example, Oyserman, Bybee, Terry, and Hart-Johnson (2004) showed that future selves were related to achievement goals, and in turn, to academic performance in children. Krishnamurthy and Sujan (1999) found that adults with better self-referencing imagery about the future developed more, and more detailed, contextually relevant thoughts, which resulted in more positive attitudes and intentions than adult with poorer future self-referencing imagery. Pham and Taylor (1999) also found that better imagining of the future (e.g., studying behaviour and 
getting good grades) increased students' likelihood of engaging in the processes that led to the desired behaviour.

Thus, positive images by an individual of their own future employability should be associated with the person engaging in detailed relevant thoughts about their current status (e.g., comparing where they are now to where they want to be; Lord, Diefendorff, Schmidt, \& Hall, 2010), and lead them to implement strategies and behaviours (i.e., self-regulate) that will maintain their progress and improve their chances of fulfilling their future image (i.e., meet their employment goals). In sum, positive future self-views will be associated with engaging in behaviours that facilitate achieving positive outcomes. By contrast, negative future self-views entail pessimistic expectations or later threatening scenarios, and tend to be associated with low engagement in goal-focused behaviours (Kornadt, Voss, \& Rotrhermund, 2015).

Future selves most likely to influence behaviour have been termed self-regulatory future selves (Oyserman et al., 2004). These typically include self-defining goals and incorporate specific behavioural strategies for pursuing those goals. In the current study, it was expected that perceived future employability would correlate positively with career ambition and university commitment, and correlate negatively with career distress. Career ambition, which is the perception of one's future career success (Greenhaus, Parasuraman, \& Wormley, 1990; Nabi, 2001), has been shown to be associated positively with individual employability (Rothwell et al., 2009), as has university commitment (Rothwell et al., 2008). As career distress reflects negative feelings toward the career decision-making process, it was expected to be associated negatively with perceived future employability (Larson, Toulouse, Ngumba, Fitzpatrick, \& Heppner, 1994). 


\section{Current study}

An individual's view of how employable they will be after completing their formal education is expected to be related to an appraisal of their current skills, experience, networks, personal traits, and their current perceived employability. When there is a discrepancy between their perceived future employability status and their current progress towards that imagined goal (e.g., appraisal that the goal might not be met), then the individual is likely to engage in behaviours that will reduce the discrepancy, or they will cognitively adjust their perceptions (e.g., lower their expectations about the future), or both (i.e., change behaviours and expectations). How close the individual comes to achieving their perceived future employability relies on the efficacy of the behaviours, and the strategies applied (i.e., how well they selfregulate; Lord et al., 2010).

Assessing the relationship between perceived future employability and current behaviours (e.g., acquired skills, self-regulatory processes) is difficult as no scale is currently adequate for making this comparison. Therefore, creating a scale to assess perceived future employability could stimulate research that can potentially enhance understanding of how young people plan for, and progress, their occupational goals. As a part of scale development, incremental validity of the newly devised scale will be assessed against an existing individual employability scale (i.e., one that measures current employability; Rothwell, Jewell, \& Hardie, 2009) when predicting study effort, which is an indicator of how well young people are striving to achieve career-related goals (Butler, 2007). Construct validity will be assessed by examining associations between perceived future employability, career-related effort, university commitment, and career distress. 


\section{Method}

\section{Phase 1: Item development}

Phase 1 consisted of generating a set of well-articulated items to form the basis for the new scale and to support content validity (Hinkin, 1998). This is important in developing a valid scale, and has been identified as best practice for scale development (Wright, Quick, Hannah, \& Hargrove, 2017). Items were generated based on findings from a review of the perceived employability literature (e.g., Berntson \& Marklund, 2007; Pool et al., 2014; Rothwell et al., 2008; van der Heijde \& van der Heijden, 2005), conducting focus groups with young adults (Vogt, King, \& King, (2004), and obtaining feedback from expert reviewers (Hinkin, 1998).

Focus groups were conducted with university and technical college students whose main role was study and preparing themselves for future employment. Twenty-two students $(\sim 50 \%$ male, aged 18-30 years) reflected on key aspects of the perceived future employability construct. The aims were to: (a) develop an understanding of young adults' perceptions of perceived future employability (What do they think it is?), (b) validate the dimensions of perceived future employability (What domains do they perceive; do these overlap with the those identified in the literature?), and (c) generate items that might be used to measure perceived future employability (e.g., What questions might they ask?). These steps were designed to support content validity for the scale (Hinkin, 1998; Vogt et al., 2004). The focus group discussions were audio taped, transcribed, and used as a reference for item development.

A content analysis of the perceived future employability construct derived from the literature and the focus groups identified six potential dimensions of the construct: (a) skills, (b) accumulated experiences, (c) personal characteristics, (d) networks, (e) labour market knowledge, and (f) reputation of educational institution attended (see Table 1). Based on this 
analysis, and consistent with Hinkin's (1998) recommendation to generate approximately twice the number of items required for the final scale, 42 items were generated to cover the six dimensions. The aim was to develop a final scale of about 20 items that would represent the construct, and which would minimize possible response biases due to boredom or fatigue (Schmitt \& Stutts, 1985; Schriesheim \& Eisenbach, 1995).

Ten independent experts, including career development practitioners, researchers, and psychometric experts, who were independent from the researchers conducting the study, reviewed the 42 items. The experts rated each item as to how well it represented its nominated dimension, commented on the phrasing, and made suggestions for improvement or rewording to replace any items that they considered problematic. For all items, at least six experts rated them as adequate or better; thus, after some minor adjustments, all 42 were retained. The items were also tested for readability using the Flesch Reading Ease scale (readability score $=58.7 / 100$ ), and the Flesch-Kincaid Grade Level measure (readability grade level 8.9), indicating that the items were suitable for respondents with Grade 9 level schooling or better (Calderon, Morales, Liu, \& Hays, 2006). After piloting the items with a small group of the target population $(N=7)$, the 42 items, together with demographic questions and two scales used to assess incremental validity, were compiled into a questionnaire and administered to a sample of university students.

\section{Phase 2: Item analysis and exploratory factor analysis}

The aim of this phase was to identify items to be retained in the new scale, which was labelled the Perceived Future Employability Scale (PFES), using item analysis and exploratory factor analysis. 


\section{Participants}

These were 324 young adults $(62.3 \%$ female, mean age 20.77 years, $S D=5.70$, range 17 30). Mean self-reported academic level in the final year of high school was $1.90(S D=0.67 ; 5$ point scale from 1 very high achievement to 5 very limited achievement). As a proxy for socioeconomic status (cf. European Social Survey, 2010), participants indicated, compared to their peers, how they would describe their current economic position: $18(5.6 \%)$ indicated they were much better off than others, 83 (25.6\%) a little better off, 146 (45\%) about the same, 68 (21\%) a little worse off, and $9(2.8 \%)$ much worse off than others $($ mean $=2.90 ; S D=0.89)$. Participants were mainly domestic students, with a small number of international students, recruited from one university in a large regional city on the east coast of Australia. As is typical of Australian universities, the participating university population comprised approximately $89 \%$ domestic Australian (mainly Caucasian) students.

\section{Materials}

Perceived Future Employability Scale. These were the 42 items generated in Phase 1, which were developed to reflect the six potential domains of perceived future employability (future skills, accumulated experiences, personal characteristics, networks, labour market knowledge, and reputation of educational institution attended). Participants responded to each item with a Likert-type format, with options ranging from 1 strongly disagree to 6 strongly agree.

Individual Employability Scale. This was assessed using the 6-item Individual Employability Scale (Rothwell et al., 2009), which assessed students' current perceived employability. A sample item is, "The skills and abilities that I possess are what employers are looking for" (response option from 1 strongly disagree to 6 strongly agree). The scale 
developers reported an internal reliability coefficient of .72, and supported validity by finding that the scale related positively to student ambition and university commitment (Rothwell et al., 2009). Alpha for the current sample was .85.

Study effort. The 9-item University Effort Scale (Butler, 2007) measures effort expended on various tasks related to university achievement. A sample item is, "I put in a high level of effort at my studies" (response format from 1 strongly disagree to 6 strongly agree). Butler (2007) reported an alpha internal reliability of .88 , and found the scale to be related positively to attendance, GPA, and university satisfaction, as expected. Cronbach's alpha for the current sample was .90 .

\section{Procedure}

The authors' University Human Research Ethics Committee approved the study. The online survey was advertised via a university-wide email sent to all students. Participants could enter a prize draw for a $\$ 50$ shopping voucher.

\section{Results}

\section{Item analysis}

Item distributions were assessed (heavily skewed and kurtotic items were marked for deletion), inter-item correlations were calculated (correlations $\geq .80$ were marked for deletion), and corrected item-total correlations were examined (correlations $\leq 30$ were marked for deletion; Gorsuch, 1997; Klein, 2000). No items were removed based on these analyses.

\section{Exploratory factor analysis}

The Kaiser-Meyer-Olkin measure of sampling adequacy (.94) and Bartlett's test of sphericity $(p<.001)$ indicated that the 42 items were suitable for factor analysis. Factor analyses were conducted using principal axis factoring extraction, and direct oblimin rotations, as the 
underlying domains were expected to be correlated (Hair, Black, Babin, \& Anderson, 2010).

Recommendations by Hayton, Allen, and Scarpello (2004), Hinkin (1998), Kahn (2006), O’Connor (2000), and Patil, Singh, Mishra, and Donovan (2008) were followed. A combination of decision rules was used to determine the number of factors to be retained, including the scree plot, Velicer's minimum average partial test, parallel analysis (O’Connor, 2000), a minimum of three items per factor (Costello \& Osborne, 2005), and factor interpretability (Hinkin, 1998).

The scree plot, Velicer's minimum average partial test, and a parallel analysis all indicated a 6-factor solution. Being consistent with our expected six domains, this solution was accepted for the PFES. Items with factor loadings $<.40$ or cross-loading items ( $\geq .30$; Costello \& Osborne, 2005) were deleted one at a time, and the analysis was re-run after each item deletion. This left 24 items ( 4 per factor) accounting for $79.03 \%$ of the variance, exceeding the recommended minimum 60\% target (Hinkin, 1998). All items showed acceptable corrected item-total correlations (range .53 to .95 ; Costello \& Osborne, 2005). See Table 2 for final item selection and factor loadings.

\section{Incremental validity check}

As an initial test of the incremental validity, and thus, usefulness of the PFES (cf. Heynes \& Lench, 2003), a hierarchical linear multiple regression analysis was undertaken to establish whether the PFES explained additional variance in a relevant variable (i.e., study effort) over and above that explained by an existing measure of employability (i.e., the Individual Employability Scale; Rothwell et al., 2009). At Step 1 in the regression analysis, the Individual Employability Scale accounted for $8.5 \%$ of the variance in study effort, $F(1,322)=30.82 ; p<.001$. At Step 2, the PFES total score accounted for an additional $7.3 \%$ of the variance $(15.8 \%$ total variance explained), $F_{\text {Change }}(1,321)=27.98 ; p<.001$, suggesting that the PFES was a better predictor of 
student striving than an existing measure of current perceived employability, as would be expected from future selves theory (Markus \& Nurius, 1986).

\section{Phase 3: Confirmatory factor analyses}

The aim of this phase was to confirm the factor structure of the PFES on a second sample of students.

\section{Participants}

Participants were a new sample of 250 students ( $83.2 \%$ female, mean age 21.18 years, $S D=$ 4.34, range 17-30), recruited from the same institutions as for Phases 1 and 2, and answered the same biographic questions. The sample was primarily domestic and Caucasian (61\%), had a mean self-reported academic level from final year of high school of $2.02(S D=0.67)$ and a mean SES of $2.96(S D=0.94)$.

\section{Materials}

Perceived Future Employability. The 24-item PFES developed in Phases 1 and 2 was used in these analyses (6-point response format from 1 strongly disagree to 6 strongly agree; see Table 2 for full stem and items). Internal reliability coefficients with this sample were .95 (full scale), .88 (future skills), .92 (accumulated experiences), .88 (personal characteristics), .95 (networks), .91 (labour market knowledge), and .89 (reputation of educational institution attended).

Career ambition. A 6-item Career Ambition Scale, which was derived from the Individual Employability Scale (Rothwell et al., 2009), was used to represent perceptions of future career success. A sample item was, "I am satisfied with the progress I have made meeting my goals for career development" (response format from 1 strongly disagree to 6 strongly agree). This scale has been used previously with young adults, where validity was supported by showing that the 
scale related positively to perceived employability and university commitment (Rothwell et al., 2009). The internal reliability coefficient for the current sample was .77.

University commitment. The 7-item University Commitment Scale measured participants' commitment to their tertiary institution (Rothwell et al., 2008). A sample item was, "I am extremely glad I chose this university over others I was considering at the time I joined" (response format from 1 strongly disagree to 6 strongly agree). The scale has demonstrated good psychometric properties with young adult samples, including an internal reliability coefficient of .87 , and correlations with other scales, such as perceived employability, in the expected direction. Alpha for the current sample was .92 .

Career distress. This was measured with the 9-item Career Distress Scale (Creed, Hood, Praskova, \& Makransky, 2016) A sample item was, "I often feel down or depressed about selecting a career" (response format from 1 strongly disagree to 6 strongly agree). The scale has good psychometric properties with young adults, including an internal reliability of .90 and, in support of validity, negative associations with positive affect and positive associations with negative affect (Creed et al., 2016). Alpha for the current sample was .93.

\section{Results}

Confirmatory factor analysis (CFA; AMOS v24), which can assess how well obtained data fit a proposed factor structure (van Proojien \& van der Kloot, 2001), was used to test the factor structure of the 24-item PFES identified in Phase 2. Four models were assessed. First, a 6-factor model representing the six factors identified in Phase 2 was tested. In this model, each cluster of four items identified in Phase 2 was assigned to its respective latent variable, and correlations among the six latent variables were freely estimated. Second, a single-factor model with all items loaded onto a single latent variable was tested. This model assessed whether all items could be 
represented by a unidimensional scale. Third, a second-order, hierarchical model with a single, second-order latent variable representing the six factors from Phase 2 was tested. This model assessed whether the six factors could be represented by a single, higher level factor. Fourth, a bifactor model was tested, in which each item was allowed to load on a general factor, as well as to load onto each factor individually. This model assessed the proportion of common item variance accounted for by the general factor, while controlling for the group factors, and viceversa.

Model fit was assessed using $\chi^{2}$, normed $\chi^{2}\left(\chi^{2} / d f\right)$, Comparative Fit Index (CFI), and Root Mean Square Error of Approximation (RMSEA), as suggested by Hair et al. (2010). With 250 participants and 24 observed variables, a significant $\chi^{2}$ value is expected, and $\chi^{2} / d f<3.0$, CFI $>.92$, and RMSEA $<.05$ indicate an acceptable fit. Differences between the non-embedded models were assessed using the Akaike Information Criterion (AIC), with the lower values indicating better fit (Hair et al., 2010).

Fit statistics for the four models are in Table 3. Summary data and bivariate correlations among scales are in Table 4. All models produced a satisfactory fit except for the 1-factor model; thereby ruling this model out as a potential fit for the data. Of the remaining three models (6factor, 2nd-order, and bifactor), the bifactor model had the best fit statistics and the lowest AIC. Thus, the bifactor model was accepted as the best representation of the data. A bifactor model is a latent structure with individual items loading onto a general factor, which reflects what is common among the items, and also loading onto the individual factors, which represent individual differences among the target dimensions. A bifactor structure specifies two or more orthogonal "group" factors. These group factors (in this case, future skills, accumulated experiences, personal characteristics, networks, labour market knowledge, and reputation of 
educational institution attended) represent common factors explaining item response variance not accounted for by the general factor.

The 6-factor, 2nd-order, and bifactor models all supported multi-dimensionality of the PFES. However, despite this demonstrated multi-dimensionality, it still needs to be determined whether the PFES is better reflected as a general factor (i.e., used at the total score level), or whether it is more reliably interpreted at the specific factor level (i.e., at the subscale level). Based on recommendations by Rodriguez, Reise, and Haviland (2016), and using the Bifactor Indices Calculator (Dueber, 2017), four bifactor coefficients (Omega, OmegaH, Relative Omega, and the explained common variance) were calculated to aid with this determination.

Omega, which is the model-based reliability estimate reflecting the proportion of variance accounted for when considering all items, was .97 for the general factor, and $.88, .92, .88, .95$, .91 , and .90 for the specific factors, indicating good reliability for the general factor and sound to good reliability for the specific factors. OmegaH, the proportion of unique variance accounted for by the general factor, was .86; the OmegaH coefficients for the specific factors were .38 (future skills), .34 (accumulated experiences), .53 (personal characteristics), .46 (networks), .19 (labour market knowledge), and .53 (reputation of educational institution). When OmegaH $>.80$, a multidimensional construct is better considered at the total item level, rather than the subscale level (Rodriguez et al., 2016). Relative Omega is the proportion of reliable variance due to a factor. For the general factor, this was .88; for the specific factors, the statistics were $.43, .37$, $.60, .48, .21$, and .59 , respectively; again, supporting interpretation at the general factor level. Last, the explained common variance, or the proportion of common variance explained by a factor, was .55 for the general factor, and $.07, .07, .09, .09, .04$, and .09 , respectively, for the specific factors. These results suggested that using the global score would provide the most 
meaningful measure of perceived future employability, with much less variance accounted for when interpreted at the subscale level; that is, the scale is best applied at a global level.

\section{Phase 4: Construct validity}

The aim of this phase was to provide initial support for construct validity of the scale by correlating the total PFES score with scores from measures of career ambition, university commitment, and career distress. As expected, positive correlations were found between PFES total and career ambition $(r=.65)$ and university commitment $(r=.59)$, and the PFES was correlated negatively with career distress $(r=-.39)$, indicating that the PFES was related appropriately to variables identified in its nomological net. We also noted that the PFES total score was uncorrelated with age and gender, suggesting no inherent bias in the scale in relation to these variables.

\section{Discussion}

This study reported on the development and validation of a measure of young adults' perceived future employability, which concerns their perceptions of their future skills, experience, networks, personal traits, labour market knowledge, and institutional reputation at the time of completing their formal education when they are on the verge of entering the labour market. This employability concept is important as an emerging quality that can enable workers to adapt and thrive in the contemporary workforce. No scales had previously been developed specifically to assess perceived future employability in young adults, who have as one of their main developmental foci their future career.

The study advances theoretical understanding of how perceived future employability is manifested in young adults who are preparing themselves for the workforce. It also contributes to the existing, but limited, perceived employability literature, which has focused primarily on 
working adults, and within organizational contexts that involved employees and job seekers who were moving, or who had been forced to move, between employers. Based on the perceived employability literature (e.g., Berntson \& Marklund, 2007; Rothwell \& Arnold, 2007), perceived future employability was operationalized as a multidimensional construct (i.e., perceptions of future skills, experience, networks, personal traits, labour market knowledge, and institutional reputation).

A psychometrically sound, 24-item measure was devised to assess perceived future employability (i.e., the PFES). Subsequent analyses supported that the PFES was multi-factorial, but that it should be interpreted using the global-level score rather than at the subscale level. The global measure was found to have good internal reliability, and initial evidence for the validity of the measure was also obtained. First, the study demonstrated that the PFES accounted for additional variance in study effort, an important variable representing student goal-striving, over and above that explained by an existing employability scale. Second, the PFES was shown to be related to other important career variables (i.e., career ambition, university commitment, and career distress) in expected ways.

The scale can be used to examine perceived future employability in young adult, college/university students. This will allow scholars to test the correlates of perceived future employability (e.g., motivation, performance, well-being), and to test how these relationships change over time as perceived future employability changes. For university students, (current perceptions of) employability has been related to constructs such as self-efficacy, self-esteem, and self-confidence (Pool \& Sewell, 2007). For adults, employability has been associated negatively with job insecurity (Berntson et al., 2010; De Cuyper, Mäkikangas, Kinnunen, \& Mauno, 2012), burnout (Aybas, Elmas, \& Dündar, 2015), and other job-related maladjustments 
(Berntson et al., 2010). It has also been associated positively with job search behaviours (Chen \& Lim, 2012), adaptation to change (Berntson, Sverke, \& Marklund, 2006; Fugate et al., 2004), job satisfaction (Giorgi, Shoss, \& Leon-Perez, 2015), and well-being (Berntson \& Marklund, 2007; Silla, De Cuyper, Gracia, Peiró, \& De Witte, 2009). However, previous research has primarily used workplace samples and examined current employability. It remains to be determined how perceived future employability relates to important variables for young adults who are not currently employed.

Caricati, Chiesa, Guglielmi, and Mariani (2016) suggested that perceived employability could be linked credibly to employment success. Demonstrating a connection between perceived future employability and labour market outcomes will support the predictive validity of the PFES, and inform interventions that could boost students' realistic employability perceptions, and provide them with the most efficacious strategies. If predictive validity is demonstrated, this will also enable an evaluation of how well universities and other training/educational bodies are accomplishing the task of building bridges between the educational system and the labour market. Tomlinson (2012) noted that: “...some students on the point of transiting to employment are significantly more orientated towards the labour market than others" (p. 422). Further research is needed to explain this variability; for example, do students who invest in longer and more demanding academic curricula develop stronger identities and forms of identification with a specific future pathway, or are other variables operating? Studies have found that higher levels of education are associated with stronger perception of employability (Berntson et al., 2006; Wittekind, Raeder, \& Grote, 2010).

This new scale could also be useful as a screening device for use by academic advisors, counsellors, student services' personnel, human resource professionals, and others who work 
with students who are preparing themselves for future employment. An examination of item and subscale responses could alert practitioners to the multiple dimensions of perceived future employability. This might assist them to help students develop those aspects of their future view that are most problematic, and allow them to provide targeted, effective strategies to enhance student employability.

\section{Limitations}

The study was conducted at one university in one country, and the applicability of the scale needs to be tested in other samples. The current study sample also contained disproportionately more female than male students, and a majority of participants were enrolled in social science and health courses. No significant association was found between PFES and gender (or age), and there is no reason to expect that men and women studying at university level would report different levels (cf. Caricati et al., 2016). However, validation of the scale in more diverse samples, where there is a more equal gender balance, needs to be undertaken. This would allow, for example, testing for gender (and age and other) invariance. Last, it was not possible to test the predictive validity of the new measure. This would mean, for example, assessing whether higher scale scores at one point in time were associated with stronger academic engagement and better well-being later, for which longitudinal studies will be required. Assessing test-retest reliability is another task for future studies.

\section{Conclusion}

The findings indicated that this newly developed PFES measure shows promise as a reliable and valid measure of perceived future employability in young adults. Further research with the scale is needed to augment validity, but having a scale to assess perceived future employability in young adults will allow researchers to develop a better understanding of young people's 
perceptions of their occupational futures and how these relate to current behaviour, cognitions, and affect.

\section{Conflict of Interest and Funding}

The authors declare no conflict of interest with respect to the research, authorship, and/or publication of this article, and received no financial support for the study.

\section{References}

Akkermans, J., \& Kubasch, S. (2017). Trending topics in careers: a review and future research agenda. Career Development International, 22, 586-627. doi:10.1108/CDI-08-2017-0143 Aybas, M., Elmas, S., \& Dündar, G. I. (2015). Job insecurity and burnout: The moderating role of employability. European Journal of Business and Management, 7, 195-202. Available online: www.iiste.org/Journals/index.php/EJBM/article/viewFile/21200/21544

Berntson, E. (2008). Employability perceptions: Nature, determinants, and implications for health and well-being (PhD Thesis). Stockholm, Sweden: Stockholm University.

Berntson, E., \& Marklund, S. (2007). The relationship between perceived employability and subsequent health. Work and Stress, 21, 279-292. doi:10.1080/02678370701659215

Berntson, E., Näswall, K., \& Sverke, M. (2010). Investigating the relationship between employability and self-efficacy: A cross-lagged analysis. European Journal of Work and Organizational Psychology, 17, 413-425. doi:10.1080/13594320801969699

Berntson, E., Sverke, M., \& Marklund, S. (2006). Predicting perceived employability: Human capital or labour market opportunities? Economic and Industrial Democracy, 27, 223-244. doi:10.1177/0143831X06063098

Bricout, J. C., \& Bentley, K. J. (2000). Disability status and perceptions of employability by employers. Social Work Research, 24, 87-95. doi:10.1093/swr/24.2.87Butler, A. B. (2007). 
Job characteristics and college performance and attitudes: A model of work-school conflict and facilitation. Journal of Applied Psychology, 92, 500-510.

http://dx.doi.org/10.1037/0021-9010.92.2.500.

Calderon, J. L., Morales, L. S., Liu, H., \& Hays, R. D. (2006). Variation in the readability of items within surveys. American Journal of Medical Quality, 21, 49-56.

doi:10.1177/1062860605283572

Caricati, L., Chiesa, R., Guglielmi, D., \& Mariani, M. G. (2016). Real and perceived employability: A comparison among Italian graduates. Journal of Higher Education Policy and Management, 38, 490-502. Retrieved from http://www-tandfonlinecom.libraryproxy.griffith.edu.au/loi/cjhe20

Chen, D. Q., \& Lim, V. G. (2012). Strength in adversity: The influence of psychological capital on job search. Journal of Organizational Behavior, 33, 811-839. doi:10.1002/job.1814

Comello, M. L. (2015). How does a risk-oriented "future-self” influence behavior? A structuralequation-modeling approach with marijuana-related outcomes. Journal of Health Psychology, 20, 37-47. doi:10.1177/1359105313498107

Costello, A. B., \& Osborne, J. W. (2005). Best practices in exploratory factor analysis: Four recommendations for getting the most from your analysis. Practical Assessment, Research \& Evaluation, 10, 1-9. Available online: https://pareonline.net/pdf/v10n7.pdf

Creed, P. A., Hood, M., Praskova, A., \& Makransky, G. (2016). The Career Distress Scale: Using Rasch measurement theory to evaluate a brief measure of career distress. Journal of Career Assessment, 24, 732-746. doi:10.1177/1069072715616126 
Creed, P. A., \& Klisch, J. (2005). Future outlook and financial strain: Testing the personal agency and latent deprivation models of unemployment and well-being. Journal of Occupational Health Psychology, 10, 251-260. doi:10.1037/1076-8998.10.3.251

Cross, S., \& Markus, H. (1991). Possible selves across the life-span. Human Development, 34, 225-230. doi:10.1159/000277058

De Cuyper, N., \& De Witte, H. (2010). Temporary employment and perceived employability: Mediation by impression management. Journal of Career Development, 37, 635-652. doi:10.1177/0894845309357051

De Cuyper, N., Mäkikangas, A., Kinnunen, U., \& Mauno, S. (2012). Cross-lagged associations between perceived external employability, job insecurity, and exhaustion: Testing gain and loss spirals according to the Conservation of Resources Theory. Journal of Organizational Behavior, 33, 770-788. doi:10.1002/job.1800

DiRenzo, M. S., Greenhaus, J. H., \& Weer, C. H. (2011). Job level, demands, and resources as antecedents of work-family conflict. Journal of Vocational Behavior, 78, 305-314. doi:10.1016/j.jvb.2010.10.002

Dueber, D. M. (2017). Bifactor Indices Calculator: A Microsoft Excel-based tool to calculate various indices relevant to bifactor CFA models. https://dx.doi.org/10.13023/edp.tool.01 [Available at http://sites.education.uky.edu/apslab/resources/]

Ellen, P. S., Wiener, J. L., \& Fitzgerald, M. P. (2012). Encouraging people to save for their future: Augmenting current efforts with positive visions of the future. Journal of Public Policy \& Marketing, 31, 58-72. doi:10.1509/jppm.09.089 
European Social Survey (2010). ESS round 5 source questionnaire. London, UK: Centre for Comparative Social Surveys (Retrieved from http://www.europeansocialsurvey.org/methodology/questionnaire/

Fugate, M., Kinicki, A. J., \& Ashforth, B. E. (2004). Employability: A psycho-social construct, its dimensions, and applications. Journal of Vocational Behavior, 65, 14-38. doi:10.1016/j. jvb.2003.10.005

Gazier, B. (1998). Employability: Definitions and trends. In B. Gazier (Ed.), Employability: Concepts and policies (pp. 37-71). Berlin, Germany: European Employment Observatory.

Giorgi, G., Shoss, M. K., \& Leon-Perez, J. M. (2015). Going beyond workplace stressors: Economic crisis and perceived employability in relation to psychological distress and job dissatisfaction. International Journal of Stress Management, 22, 137-158. doi:10.1037/a0038900

Gorsuch, R. L. (1997). Exploratory factor analysis: Its role in item analysis. Journal of Personality Assessment, 68, 532-560. doi:10.1207/s15327752jpa6803_5

Graffam, J., Shinkfield, A. J., \& Hardcastle, L. (2008). The perceived employability of exprisoners and offenders. International Journal of Offender Therapy and Comparative Criminology, 52, 673-685. doi:10.1177/0306624X07307783

Greenhaus, J. H., Parasuraman, S., \& Wormley, W. M. (1990). Effects of race on organizational experiences, job performance evaluations, and career outcomes. Academy of Management Journal, 33, 64-86. doi:10.2307/256352

Guilbert, L., Bernaud, J., Gouvernet, B., \& Rossier , J. (2016). Employability: Review and research prospects. International Journal for Educational and Vocational Guidance, 16, 6989. doi:10.1007/s10775-015-9288-4 
Hair, J. F., Black, W. C., Babin, B. J., \& Anderson, R. E. (2010). Multivariate data analysis. A global perspective (7th ed.). Upper Saddle River, NJ: Prentice Hall.

Harvey, L. (2001). Defining and measuring employability. Quality in Higher Education, 7, 97110. doi:10.1080/13538320120059990

Haynes, S.N. \& Lench, H.C. (2003). Incremental validity of new clinical assessment measures. Psychological Assessment, 15, 456-66. doi:10.1037/1040-3590.15.4.456

Hayton, J. C., Allen, D. G., \& Scarpello, V. (2004). Factor retention decisions in exploratory factor analysis: A tutorial on parallel analysis. Organizational Research Methods, 7, 191205. doi:10.1177/1094428104263675

Hillage, J., \& Pollard, E. (1998). Employability: Developing a framework for policy analysis. (Research report RR85). Brighton, UK: Institute for Employment Studies. Retrieved from https://goo.gl/z68mlS

Hinkin, T. R. (1998). A brief tutorial on the development of measures for the use in survey questionnaires. Organizational Research Methods, 1, 104-121. doi:10.1177/109442819800100106

Kahn, J. H. (2006). Factor analysis in counseling psychology research, training, and practice. The Counseling Psychologist, 34, 684-718. doi:10.1177/0011000006286347

Klein, P. (2000). The handbook of psychological testing (2nd ed.). London, UK: Routledge.

Knight, P., \& Yorke, M. (2004). Learning, curriculum and employability in higher education. London, UK: Routledge Falmer.

Koen, J., Klehe, U., \& Van Vianen, A. E. M. (2013). Employability among the long-term unemployed: A futile quest or worth the effort? Journal of Vocational Behavior, 82, 37-48 doi:10.1016/j.jvb.2012.11.001 
Kornadt, A. E., Voss, P., \& Rothermund, K. (2015). Hope for the best, prepare for the worst? Future self-views and preparation for age-related changes. Psychology and Aging, 30, 967976. doi:10.1037/pag0000048

Krishnamurthy, P., \& Sujan, M. (1999). Retrospection versus anticipation: The role of the ad under retrospective and anticipatory self-referencing. Journal of Consumer Research, 26, 55-69. doi:10.1086/209550

Larson, L. M., Toulouse, A. L., Ngumba, W. E., Fitzpatrick, L. A., \& Heppner, P. P. (1994). The development and validation of coping with career indecision. Journal of Career Assessment, 2, 91-110. doi:10.1177/106907279400200201

Lord, R. G., Diefendorff, J. M., Schmidt, A. M., \& Hall, R. J. (2010). Self-regulation at work. Annual Review of Psychology, 61, 543-568. doi:10.1146/annurevpsych.093308. 100314

Markus, H., \& Nurius, P. (1986). Possible selves. American Psychologist, 41, 954-969. doi:10.1037/0003-066X.41.9.954

McArdle, S., Waters, L., Briscoe, J. P., \& Hall, D. (2007). Employability during unemployment: Adaptability, career identity and human and social capital. Journal of Vocational Behavior, 71, 247-264. doi:10.1016/j.jvb.2007.06.003

Nabi, G. R. (2001). The relationship between HRM, social support and subjective career success among men and women. International Journal of Manpower, 22, 457-474. doi:10.1108/EUM0000000005850

O’Connor, B. (2000). SPSS and SAS programs for determining the number of components using parallel analysis and Velicer's MAP test. Behavior Research Methods, 32, 396-402. doi:10.3758/bf03200807 
Oyserman, D., Bybee, D., Terry, K., \& Hart-Johnson, T. (2004). Possible selves as roadmaps. Journal of Research in Personality, 38, 130-149. doi:10.1016/S0092-6566(03)00057-6

Patil, V. H., Singh, S. N., Mishra, S., \& Donovan, D. T. (2008). Efficient theory development and factor retention criteria: Abandon the 'eigenvalue greater than one' criterion. Journal of Business Research, 61, 162-170. doi:10.1016/j.jbusres.2007.05.008

Pham, L. B., \& Taylor, S. E. (1999). From thought to action: Effects of process- versus outcomebased mental simulation on performance. Personality and Social Psychology Bulletin, 25, 250-260. doi:10.1177/0146167299025002010

Pool, L. D., \& Qualter, P. (2013). Emotional self-efficacy, graduate employability, and career satisfaction: Testing the associations. Australian Journal of Psychology, 65, 214-223. doi:10.1111/ajpy.12023

Pool, L. D., Qualter, P., \& Sewell, P. J. (2014). Exploring the factor structure of the CareerEDGE employability development profile. Education and Training, 56, 303-313. doi:10.1108/ET-01-2013-0009

Pool, L. D., \& Sewell, P. J. (2007). The key to employability: Developing a practical model of graduate employability. Education \& Training, 49, 277-289. doi:10.1108/00400910710754435

Rodriguez, A., Reise, S. P., \& Haviland, M. G. (2016). Evaluating bifactor models: Calculating and interpreting statistical indices. Psychological Methods, 21, 137-150. doi:10.1037/met0000045

Rothwell, A., \& Arnold, J. (2007). Self-perceived employability: Development and validation of a scale. Personnel Review, 36, 23-41. doi:10.1108/00483480710716704 
Rothwell, A., Herbert, I., \& Rothwell, F. (2008). Self-perceived employability: Construction and initial validation of a scale for university students. Journal of Vocational Behavior, 73, 1-12. doi:10.1016/j.jvb.2007.12.001.

Rothwell, A., Jewell, S., \& Hardie, M. (2009). Self-perceived employability: Investigating the responses of post-graduate students. Journal of Vocational Behavior, 75, 152-161. doi:10.1016/j.jvb.2009.05.002

Schmitt, N., \& Stutts, D. M. (1985). Factors defined by negatively keyed items: The result of careless respondents? Applied Psychological Measurement, 9, 367-373. doi:10.1177/014662168500900405

Schriesheim, C. A., \& Eisenbach, R. J. (1995). An exploratory and confirmatory factor-analytic investigation of item wording effects on the obtained factor structures of survey questionnaire measures. Journal of Management, 21, 1177-1193.

doi:10.1177/014920639502100609

Silla, I., De Cuyper, N., Gracia, F. J., Peiró, J. M., \& De Witte, H. (2009). Job insecurity and well-being: Moderation by employability. Journal of Happiness Studies, 10, 739-751. doi:10.1007/ s10902-008-9119-0

Tomlinson, M. (2012). Graduate employability: A review of conceptual and empirical themes. Higher Education Policy, 25, 407-431. doi:10.1057/hep.2011.26

Vanhercke, D., De Cuyper, N., Peeters, E., \& De Witte, H. (2014). Defining perceived employability: A psychological approach. Personnel Review, 43, 592-605. doi:10.1016/j.ics.2005.02.061. 
Van der Heijde, C. M. (2014). Employability and self-regulation in contemporary careers. In M. Coetzee (Ed.), Psycho-social career meta-capacities: Dynamics of contemporary career development (pp. 7-17). Dordrecht, the Netherlands: Springer.

Van der Heijde, C. M., \& van der Heijden, B. I. (2005). The development and psychometric evaluation of a multi-dimensional measurement instrument of employability — and the impact of aging. International Congress Series, 1280, 142-147.

doi:10.1016/j.ics.2005.02.061

van Prooijen, J. W., \& van der Kloot, W. A. (2001). Confirmatory analysis of exploratively obtained factor structures. Education and Psychological Measurement, 61, 777-792. doi:10.1177/00131640121971518

Vogt, D. S., King, D. W., \& King, L. A. (2004). Focus groups in psychological assessment: Enhancing content validity by consulting members of the target population. Psychological Assessment, 16, 231-243. doi:10.1037/1040-3590.16.3.231

Weng, Q., \& McElroy, J. C. (2012). Organizational career growth, affective occupational commitment and turnover intentions. Journal of Vocational Behavior, 80, 256-265. doi:10.1016/j.jvb.2012.01.014

Weng, Q., McElroy, J. C., Morrow, P. C., \& Liu, R. (2010). The relationship between career growth and organizational commitment. Journal of Vocational Behavior, 77, 391-400. doi:10.1016/j.jvb.2010.05.003

Wittekind, A., Raeder, S., \& Grote, G. (2010). A longitudinal study of determinants of perceived employability. Journal of Organizational Behavior, 31, 566-586. doi:10.1002/job.646

Wright, T. A., Quick, J. C., Hannah, S. T., \& Hargrove, S. T. (2017). Best practice recommendations for scale construction in organizational research: The development and 
initial validation of the Character Strength Inventory (CSI). Journal of Organizational Behavior, 38, 615-628. doi:10.1002/job.2180 
Table 1

Dimensions of Perceived Future Employability

\begin{tabular}{|c|c|c|c|c|c|c|}
\hline Published source & Dimension 1 & Dimension 2 & Dimension 3 & Dimension 4 & Dimension 5 & Other \\
\hline $\begin{array}{l}\text { Berntson \& Marklund } \\
\text { (2007) }\end{array}$ & Perceived skills & Experience & $\begin{array}{l}\text { Personal } \\
\text { characteristics }\end{array}$ & Networking & $\begin{array}{l}\text { Knowledge of labour } \\
\text { market }\end{array}$ & - \\
\hline Rothwell \& Arnold (2007) & $\begin{array}{l}\text { Transferable skills } \\
\text { and knowledge, job } \\
\text { skills }\end{array}$ & Work experience & $\begin{array}{l}\text { Learning capacity, } \\
\text { confidence, } \\
\text { organizational focus }\end{array}$ & Networking & $\begin{array}{l}\text { Awareness of } \\
\text { opportunities inside/ } \\
\text { outside organisation }\end{array}$ & - \\
\hline $\begin{array}{l}\text { Rothwell, Herbert, \& } \\
\text { Rothwell (2008) }\end{array}$ & $\begin{array}{l}\text { Education } \\
\text { achievement }\end{array}$ & - & $\begin{array}{l}\text { Vocational } \\
\text { knowledge and } \\
\text { skills, job search, } \\
\text { learning potential }\end{array}$ & - & $\begin{array}{l}\text { Awareness of } \\
\text { opportunities/demand } \\
\text { in labour market }\end{array}$ & $\begin{array}{l}\text { Reputation/image of } \\
\text { university, field of } \\
\text { study }\end{array}$ \\
\hline $\begin{array}{l}\text { van der Heijde \& van der } \\
\text { Heijden }(2005)\end{array}$ & $\begin{array}{l}\text { Occupational } \\
\text { expertise }\end{array}$ & - & $\begin{array}{l}\text { Anticipation, } \\
\text { personal flexibility } \\
\text { (adaptability) }\end{array}$ & $\begin{array}{l}\text { Social capital } \\
\text { (networking) }\end{array}$ & Corporate sense & Balance \\
\hline Knight \& Yorke (2003) & $\begin{array}{l}\text { Academic, life skills, } \\
\text { and employment }\end{array}$ & - & $\begin{array}{l}\text { Self-eficacy, } \\
\text { metacognitions }\end{array}$ & - & $\begin{array}{l}\text { Discipline knowledge, } \\
\text { business knowledge }\end{array}$ & - \\
\hline Harvey (2001) & Core work skills & - & $\begin{array}{l}\text { Interest and capacity } \\
\text { to learn, desired } \\
\text { attributes on } \\
\text { recruitment }\end{array}$ & - & Job goal & Timely job success \\
\hline Dacre Pool et al. (2014) & $\begin{array}{l}\text { Academic skills and } \\
\text { performance }\end{array}$ & $\begin{array}{l}\text { Work and life } \\
\text { experience }\end{array}$ & $\begin{array}{l}\text { Emotional } \\
\text { intelligence, problem } \\
\text { solving, self } \\
\text { management }\end{array}$ & - & $\begin{array}{l}\text { Career development } \\
\text { learning }\end{array}$ & - \\
\hline Hillage \& Pollard (1998) & $\begin{array}{l}\text { Employment, skills, } \\
\text { knowledge, and } \\
\text { attitude }\end{array}$ & - & - & - & $\begin{array}{l}\text { Career management, } \\
\text { job search skills, } \\
\text { strategic approach }\end{array}$ & $\begin{array}{l}\text { Personal situation, } \\
\text { labour market }\end{array}$ \\
\hline
\end{tabular}


Table 2

Factor Loadings for Perceived Future Employability Scale Items $(N=324)$.

\begin{tabular}{|c|c|c|c|c|c|c|}
\hline \multirow{2}{*}{$\begin{array}{l}\text { Factor } \\
\text { Item stem: "When I complete my studies..." }\end{array}$} & \multicolumn{6}{|c|}{ Factor Loading } \\
\hline & F1 & $\mathrm{F} 2$ & F3 & F4 & F5 & F6 \\
\hline \multicolumn{7}{|l|}{ Perceived future network } \\
\hline ...I will be able to draw on the network I have developed to succeed at my work & .95 & -.02 & .03 & .01 & .01 & .03 \\
\hline ...I will have built up a social network that will help me do well in my job & .92 & -.02 & .035 & .05 & .03 & .02 \\
\hline ...I will have developed a network of contacts who can help identify potential work opportunities & .80 & .11 & -.00 & .02 & -.06 & -.04 \\
\hline ...I will know how to network with people who can help me find work in my chosen career & .72 & .03 & .02 & -.02 & -.13 & .03 \\
\hline Perceived expected experiences & & & & & & \\
\hline ...I will have had relevant work experience applying the knowledge acquired in my studies & -.07 & .91 & -.03 & -.07 & .00 & .06 \\
\hline ...future employers will be impressed with the relevant work experience I have accumulated & -.10 & .87 & .01 & .10 & .03 & -.03 \\
\hline ...future employers will be satisfied with the work experiences I have gained & .04 & .66 & .14 & .10 & -.11 & .01 \\
\hline $\begin{array}{l}\text {...I will be able to show future employers that I have the required practical skills and academic experience } \\
\text { they require }\end{array}$ & .02 & .53 & -.01 & .01 & -.11 & .33 \\
\hline \multicolumn{7}{|l|}{ Perceived future personal characteristics } \\
\hline ...my experiences will show that I have developed resilience and do not give up easily & .10 & .06 & .87 & -.03 & -.06 & -.03 \\
\hline ...prospective employers will be able to see from what I have achieved that I am well motivated & -.08 & -.02 & .84 & .00 & .01 & -.01 \\
\hline ...prospective employers will be able to see that I have clear goals for myself & -.03 & .02 & .75 & -.04 & -.07 & .01 \\
\hline ...my record will show that I have a strong work ethic & -.06 & -.04 & .70 & .08 & .08 & .08 \\
\hline \multicolumn{7}{|l|}{ Anticipated reputation of educational institution } \\
\hline $\begin{array}{l}\text {...I will have an advantage as future employers will be more likely to recruit graduates from my institution } \\
\text { than from other Institutions }\end{array}$ & -.07 & .07 & .01 & .87 & .12 & -.07 \\
\hline ...the reputation of my educational institution will be a significant asset to me in job-seeking & -.01 & -.02 & .01 & .81 & .01 & .05 \\
\hline $\begin{array}{l}\text {...I will have a lot of work opportunities open to me because my teaching institution has strong partnerships } \\
\text { with many potential employers }\end{array}$ & .01 & .02 & .02 & .80 & -.10 & .02 \\
\hline $\begin{array}{l}\text {..I will be in demand because graduates from my institution are well prepared for work roles that are in } \\
\text { high demand }\end{array}$ & -.01 & -.01 & -.03 & .65 & -.21 & .11 \\
\hline \multicolumn{7}{|l|}{ Perceived future labour market knowledge } \\
\hline ...I will have developed a good understanding of the variety of work opportunities available to me & -.01 & -.05 & .04 & .04 & -.85 & .06 \\
\hline ...I will know the steps I need to take to do well in my chosen career & -.03 & .11 & .08 & .05 & -.77 & -.07 \\
\hline ...I will have developed the ability to find out about job opportunities in my chosen field & -.16 & -.02 & .06 & -.06 & -.70 & .09 \\
\hline ...I will be up-to-date with occupational trends in my chosen field & -.07 & .14 & -.03 & .09 & -.62 & .03 \\
\hline \multicolumn{7}{|l|}{$\begin{array}{l}\text { Perceived future skills } \\
\text { Pate }\end{array}$} \\
\hline ...I will have gained the knowledge required to get the job I want & -.01 & .08 & -.02 & .01 & .05 & .82 \\
\hline ...I will have the relevant skills for the occupation I choose & -.01 & -.00 & -.01 & -.09 & -.07 & .78 \\
\hline $\begin{array}{l}\text {...future employers will see that I will have learned the right discipline specific/technical skills and } \\
\text { knowledge that they want }\end{array}$ & .11 & .07 & .09 & .10 & -.08 & .70 \\
\hline ...I will have developed the reasoning and problem-solving skills that future employers often require & -.05 & -.02 & .09 & .12 & .01 & .65 \\
\hline
\end{tabular}


Table 3

Goodness-of-Fit Statistics for CFA Models $(N=250)$

\begin{tabular}{lrcccrr}
\hline Model & \multicolumn{1}{c}{$\chi^{2}$} & $\mathrm{df}$ & $\chi^{2} / \mathrm{df}$ & CFI & RMSEA & AIC \\
\hline 6-factor & $529.6^{* * *}$ & 237 & 2.2 & .94 & .07 & 655.63 \\
1-factor & $2432.9^{* * *}$ & 252 & 9.6 & .55 & .19 & 2528.95 \\
2 & $563.8^{\text {nd }}$-order factor & 246 & 2.3 & .94 & .07 & 671.78 \\
Bifactor & $471.6^{* * *}$ & 228 & 2.1 & .95 & .06 & 615.59 \\
\hline
\end{tabular}

$\chi^{2}=$ chi-square, $\mathrm{df}=$ degrees of freedom, $\mathrm{CFI}=$ Comparative Fit Index, RMSEA $=$ Root Mean

Square Error of Approximation; AIC $=$ Akaike Information Criterion; ${ }^{* * *} p<.001$. 
Table 4

Means, Standard Deviations, and Correlations among Scales

\begin{tabular}{|c|c|c|c|c|c|c|c|c|c|c|c|c|}
\hline Variable & 1 & 2 & 3 & 4 & 5 & 6 & 7 & 8 & 9 & 10 & 11 & 12 \\
\hline 1. PFES Total & - & & & & & & & & & & & \\
\hline 2. PFES F1: Skills & $.76^{* * *}$ & - & & & & & & & & & & \\
\hline 3. PFES F2: Experience & $.82^{* * *}$ & $.65^{* * *}$ & - & & & & & & & & & \\
\hline 4. PFES F3: Person characteristics & $.71^{* * *}$ & $.50^{* * *}$ & $.43^{* * *}$ & - & & & & & & & & \\
\hline 5. PFES F4: Networks & $.81^{* * *}$ & $.46^{* * *}$ & $.58^{* * *}$ & $.49^{* * *}$ & - & & & & & & & \\
\hline 6. PFES F5: Market knowledge & $.83^{* * *}$ & $.56^{* * *}$ & $.61^{* * *}$ & $.54^{* * *}$ & $.65^{* * *}$ & - & & & & & & \\
\hline 7. PFES F6: Institution reputation & $.74^{* * *}$ & $.48^{* * *}$ & $.51^{* * *}$ & $.43^{* * *}$ & $.50^{* * *}$ & $.53^{* * *}$ & - & & & & & \\
\hline 8. Career ambition & $.65^{* * *}$ & $.51^{* * *}$ & $.48^{* * *}$ & $.52^{* * *}$ & $.54^{* * *}$ & $.62^{* * *}$ & $.39^{* * *}$ & - & & & & \\
\hline 9. University commitment & $.59^{* * *}$ & $.39^{* * *}$ & $.41^{* * *}$ & $.44^{* * *}$ & $.43^{* * *}$ & $.51^{* * *}$ & $.56^{* * *}$ & $.43^{* * *}$ & - & & & \\
\hline 10. Career distress & $-.39^{* * *}$ & $-.35^{* * *}$ & $-.29^{* * *}$ & $-.34^{* * *}$ & $-.29^{* * *}$ & $-.41^{* * *}$ & $-.16^{* * *}$ & $-.45^{* * *}$ & $-.36^{* * *}$ & - & & \\
\hline 11. Age & -.04 & .03 & .04 & .09 & -.09 & -.02 & $-.19^{* *}$ & .09 & -.12 & $-.21^{* *}$ & - & \\
\hline 12. Gender & .07 & .06 & .03 & .08 & .10 & .05 & -.01 & .06 & -.11 & -.01 & -.05 & - \\
\hline Mean & 139.88 & 24.49 & 22.60 & 24.82 & 21.72 & 23.72 & 22.53 & 29.61 & 33.01 & 27.61 & 21.18 & - \\
\hline SD & 18.39 & 3.32 & 4.43 & 3.39 & 4.62 & 3.75 & 4.01 & 3.84 & 5.86 & 10.45 & 4.34 & - \\
\hline
\end{tabular}

PFES $=$ Perceived Future Employability Scale; $* * p<.01, * * * p<.001$. 